\title{
Seabed Infrastructure Projects, Underwater Cultural Heritage and The Environmental Assessment Process: The UK Example
}

\author{
Christopher Pater
}

\section{Abstract}

This chapter focuses on the legal and regulatory requirements imposed on development projects in the marine offshore areas of England, in particular the requirement to collaborate with professional archaeologists in completing Environmental Impact Assessments that include underwater cultural heritage. This chapter explains the role of Historic England in providing independent advice to developers and regulatory bodies for all aspects of the historic environment. It explains how this advice informs the preparation and approval of planning applications for offshore developments, the implementation of effective survey campaigns that include archaeological and palaeoenvironmental objectives as part of the planning application, mitigation of potential damage, protection of new discoveries and the delivery of training programmes for government administrators, archaeological consultants and industrial partners. The benefits and results of this approach are presented in the context of offshore developments such as wind farms, the laying of electricity interconnector cables, the extraction of gravel deposits and the dredging of shipping channels into ports.

\section{Pater $(\bowtie)$}

Historic England, London, UK

e-mail: chris.pater@HistoricEngland.org.uk

\section{Keywords}

Historic England · Marine infrastructure ·

Historic environment · Environmental Impact

Assessment - Written Scheme of Investigation - Archaeological Exclusion Zone · Marine planning . Wind farms

\subsection{Introduction}

This chapter focuses on the government regulations in force in the UK, and specifically in England, that require commercial and industrial companies working on the seabed to complete an Environmental Impact Assessment (EIA) in advance of development work and to carry out any mitigation required to rescue or protect environmental features of significance. The scale and intensity of offshore development in response to modern needs, especially in the sectors of sea transport and renewable energy, and the areas of seabed that can be affected by such developments are large and growing in number, emphasising the need for adequate regulation in relation to the underwater heritage (Figs. 26.1, and 26.2).

'Environment' in this context is explicitly taken to include the cultural heritage, including not only easily recognisable artefacts such as shipwrecks but also features of the prehistoric environment and archaeology such as topographic features, sediment sequences and stone 


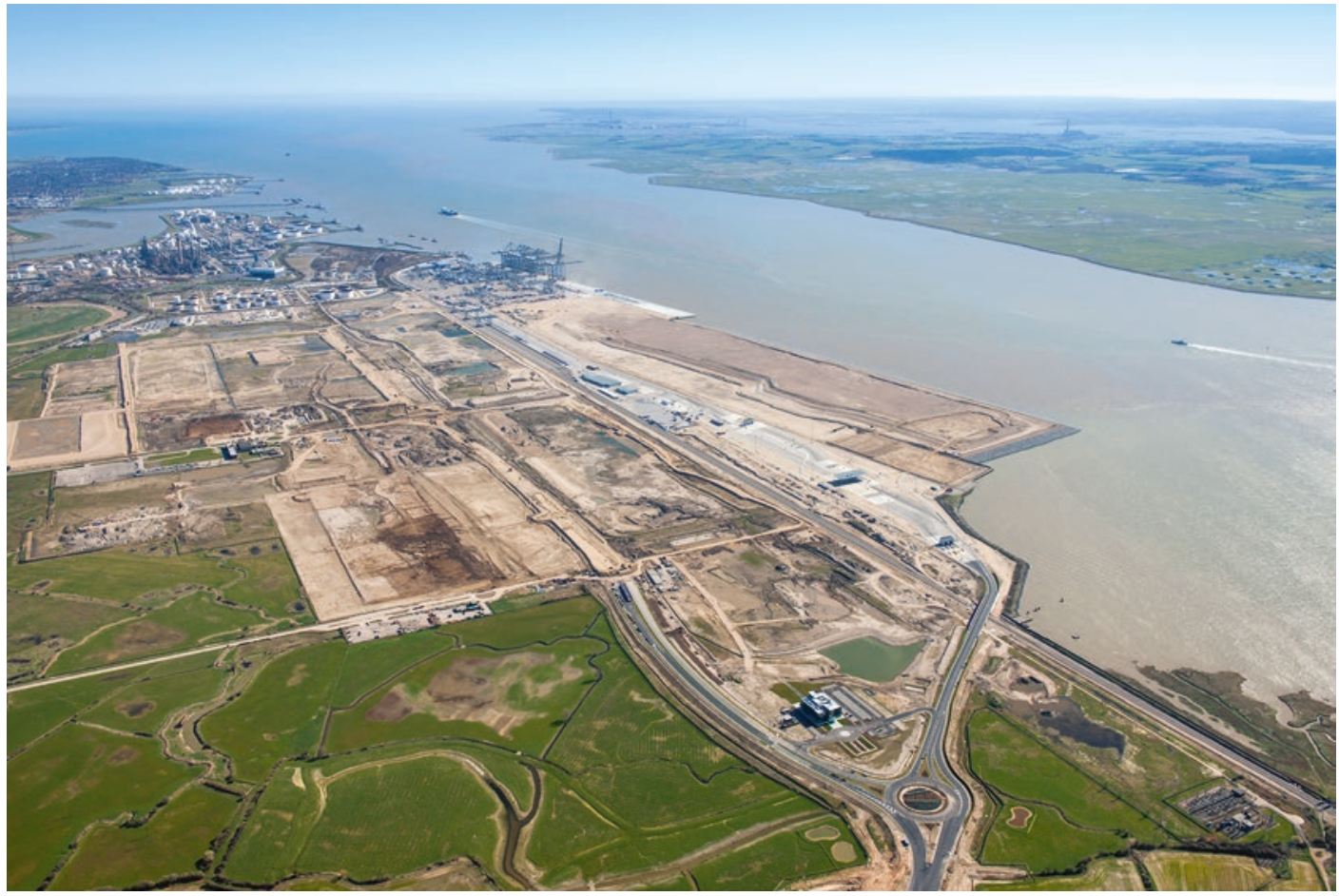

Fig. 26.1 Construction work in progress at the London Gateway Port development on the Essex coast in the Thames Estuary, giving an impression of the area affected and the potential impact on the historic environment. (C) Historic England Archive, Damian Grady

artefacts associated with the pre-inundation landscape- the 'historic environment' in English terminology. The historic environment is defined as follows:

\begin{abstract}
...all aspects of the environment resulting from the interaction between people and places through time, including all surviving physical remains of past human activity, whether visible, buried or submerged. Those elements of the historic environment - buildings, monuments, sites or landscapes - that have been positively identified as holding a degree of significance meriting consideration are called 'heritage assets'... Significance is the value of a heritage asset to this and future generations because of its heritage interest. That interest may be archaeological, architectural, artistic or historic. (HM Government and Devolved Administrations 2011, p. 21)
\end{abstract}

The offshore area that falls within UK jurisdiction, the UK Marine Area, includes the national territorial waters extending from the high water mark on the shoreline out to the limit of 12 nau- tical miles, the additional area within the Exclusive Economic Zone (EEZ), which extends out a further 188 nautical miles beyond the territorial limit - or to the median line with an adjacent maritime State, as in the North Sea-and for any areas of continental shelf that extend beyond the EEZ, which is the case for an area extending to the west of Scotland (see Dromgoole, Chap. 25, this volume, for further discussion of these terms, and HM Government and Devolved Administrations, 2011, p. 3, footnote 1 for the definition of the UK Marine Area).

Historic England (HE) is the government agency responsible for recording and researching the historic environment, operating under the UK Government Department for Digital, Culture, Media and Sport. It is the national curator for the marine (and terrestrial) historic environment and provides advice to developers, their archaeological consultants and regulators such as planning 


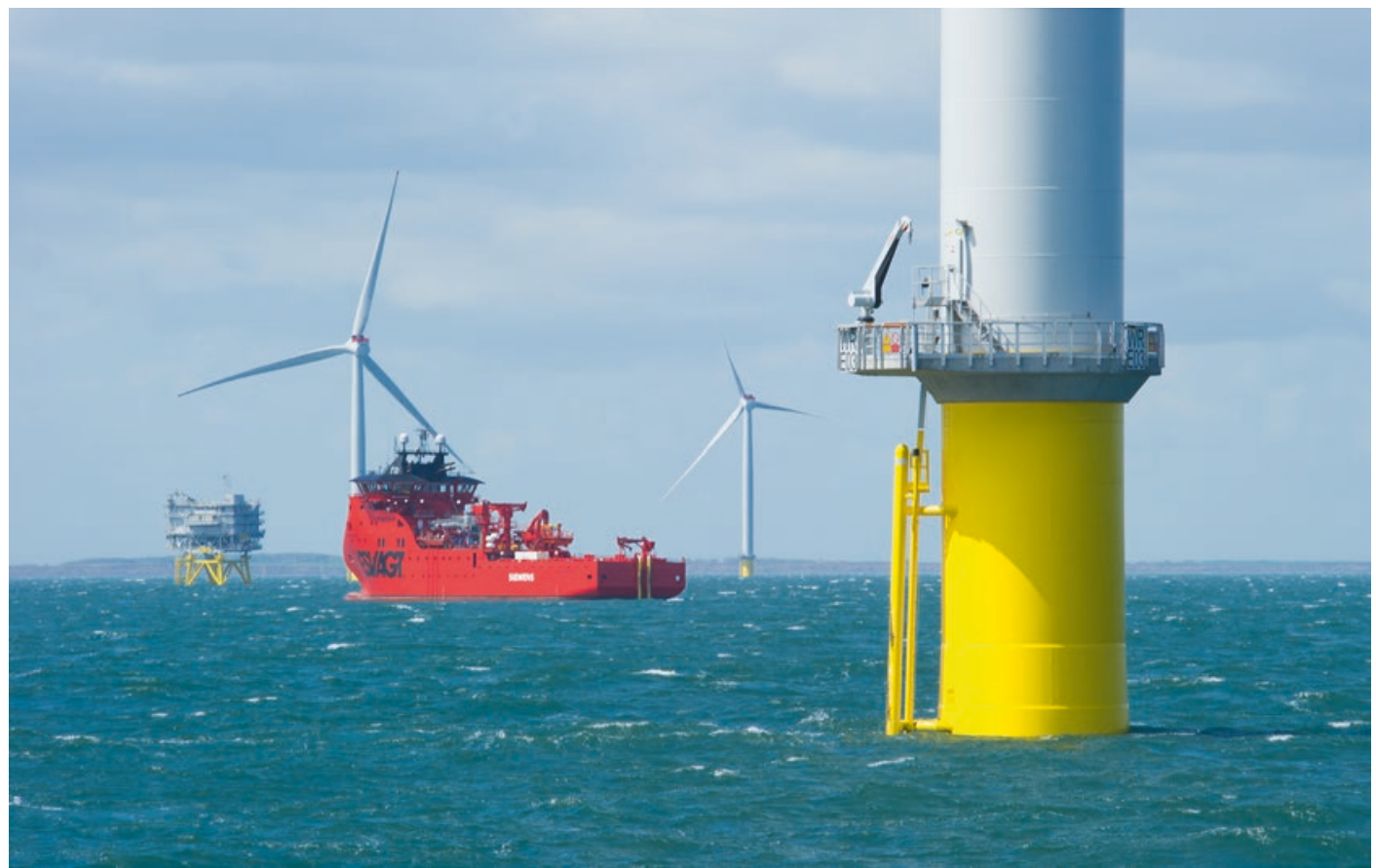

Fig. 26.2 The Westermost Rough offshore wind farm under construction, located $8 \mathrm{~km}$ offshore of the Yorkshire coast near the Humber estuary, giving some idea of the infrastructure involved in wind farm installations. The total array covers an area of $32 \mathrm{~km}^{2}$ with 35 turbines, three of which are visible in this photograph, connected by $53 \mathrm{~km}$ of submarine cables, and an offshore electricity substation, visible on the far left. The red ship is a specialist vessel for servicing the turbines. (C) Historic England Archive, Alun Bull

authorities for projects within English inshore and offshore areas. Government legislation on cultural heritage, as enshrined in the National Heritage Act of 1980 and subsequently amended, is enacted by the UK parliament in London and applies throughout the UK including the Devolved Administrations of Scotland, Wales and Northern Ireland (the latter currently suspended). However, the implementation of the law and any new legislation for cultural heritage rests with the Devolved Administrations and is carried out by different executive agencies in England, Scotland, Wales and Northern Ireland (see Bailey et al. Chap. 10, this volume; Westley and Woodman, Chap. 11, this volume). Here I deal only with the arrangements in England as a case study in the relationship between a government agency, planning authorities, offshore companies and specialists in archaeology and related disciplines and how these different partners work together to achieve the best possible outcome for the protection of the underwater heritage and the discovery of new information.

\subsection{The Role of Historic England}

Historic England is the public service established by law to provide specialist and independent advice to regulatory public bodies such as the Planning Inspectorate for nationally significant infrastructure projects or other industrial activities such as aggregate extraction, including the period before an application is submitted for examination by a regulatory authority. In doing so, Historic England provides advice directly to commercial developers and associated consultants, so that all issues to do with cultural heritage are fully considered in EIAs, which are required in support of applications for regulatory consent. However, the appreciation within UK public policy that our shared environment should be con- 
sidered inclusive of cultural heritage is relatively recent:

The United Kingdom's seas represent a valuable facet of our cultural heritage. There are the thousands of shipwrecks and remains of aircraft that one might immediately think of, but there are also drowned prehistoric landscapes containing artefacts that are more than 8,000 years old... (House of Commons Environment, Food and Rural Affairs Committee Marine Environment. Sixth Report of Session 2003-2004)

The above quote shows a broad interpretation of the marine environment and reflects the empowerment of Historic England to provide advice to government about underwater and offshore cultural heritage, following a jurisdictional amendment in 2002 to the National Heritage Act which included underwater archaeology in the territorial waters of the UK. A core responsibility is therefore to explain, protect and manage heritage assets that might be impacted by proposed development projects.

Historic England holds information and data to inform decision-making at all levels through a publicly available national archive that currently has 46,000 records including terrestrial as well as marine material (see https://www.pastscape.org. uk/, accessed 3 November 2018). These records include a diverse set of data on underwater heritage including shipwrecks, aircraft losses and other seabed anomalies of possible archaeological interest (see Bailey et al. Chap. 10, this volume, for discussion of these records in relation to prehistoric material). These records provide a key source of information to inform desk-based assessments conducted at the early stage by developers planning seabed development projects. For England, the Planning Act 2008 and the Marine and Coastal Access Act 2009 are key legislative measures that have expanded Historic England involvement in the decision-making process throughout the English sectors of the UK Marine Area (Pater and Oxley 2014).

Once a development project is submitted for regulatory permission, it is possible to secure specific conditions as part of the consent, which specify archaeological works to be completed to professional standards and thereby deliver agreed mitigation for any anticipated impacts, whether these are direct, as in the removal of identified features of possible archaeological interest, or indirect, as in the disturbance of sedimentary conditions that may cause exposure of cultural heritage materials. Crucially, this appreciation of what constitutes the underwater cultural heritage is acknowledged both strategically, that is, as government intentions regarding seabed development programmes in general, and for individual projects.

\subsection{Marine Planning and the Historic Environment}

While it is possible for individual development projects to identify mitigation measures to offset significant impact to identified cultural heritage assets, it is important that overall planning and management measures do not isolate individual components of the marine environment for attention while ignoring others. It is therefore important to emphasise that cultural heritage and other concepts such as seascape are included in the UK High Level Marine Objectives (HM Government and Devolved Administrations 2009) and within the UK Marine Policy Statement (HM Government and Devolved Administrations 2011), the latter produced as a specific requirement of the Marine and Coastal Access Act 2009. The clear explanation provided in these government publications about what comprises the marine environment, inclusive of cultural heritage, is an important matter. It is also important to note that the Marine Management Organisation (an executive non-departmental public body, sponsored by the UK Department for Environment, Food and Rural Affairs) acting as the marine planning authority, now applies such policy considerations in producing marine plans for the English sectors of the UK Offshore Marine Area (https://www.gov.uk/government/ organisations/marine-management-organisation. Accessed 3 November 2018).

Other recent government policy initiatives to promote a marine science agenda have also rec- 
ognised how studies directed at prehistoric environments can expand our knowledge and thereby support our understanding about future climate change (HM Government and Devolved Administrations 2010).

Other programmes that have strengthened the management of the marine historic environment include projects commissioned through the Aggregates Levy Sustainability Fund (20022011), such as the programme of Regional Environmental Characterisation (REC) surveys, which included archaeological objectives. For example, the Humber REC study was a multidisciplinary study of the geology, biology and archaeology of an area of $11,000 \mathrm{~km}^{2}$ off the east coast of England and demonstrated multiple benefits for effective coordination of geophysical and geotechnical data acquisition (see http:// nora.nerc.ac.uk/15037/, accessed 3 November 2018).

\subsection{Working with Seabed Industries}

The approach taken by the UK reflects differences between what the State is responsible for, strategic assessment to support leasing of areas for development, and the studies that a private developer should complete to assess the risk associated with a particular project and its impact—both positive and negative-on cultural heritage.

At the strategic level, determining how the historic environment including prehistoric landscapes might be affected by development work is informed by the European Commission's directives on Strategic Environmental Assessments (SEA Directive 2001: http://ec.europa.eu/environment/eia/sea-legalcontext.htm. Accessed 3 November 2018). At the individual project level, the EIA follows the criteria of the European Commission's directive on Environmental Impact Assessment (EIA Directive 1985 and subsequent amendments: http://ec.europa.eu/environment/ eia/eia-legalcontext.htm. Accessed 3 November 2018). The SEA approach adopted within the UK is for assessment of specified development inter- ests that the government wishes to promote, for example, licensing of oil and gas exploration and production, wind, tidal range and current devices and sub-seabed gas storage options (Department of Energy and Climate Change 2016). Such exercises are desk-based assessments of existing information conducted by consultants appointed by the responsible government department and do not necessarily include dedicated marine survey campaigns. However, mitigation principles will be defined, for example, how it might be possible to use archaeological analysis to generate new information about prehistoric environments in locations where modern seabed developments are planned.

At the individual project level, for example, construction of an offshore wind farm, the approach taken by the UK Government and Devolved Administrations is that private developers are responsible for commissioning marine survey to inform their proposed development. There is therefore a division between the strategic assessment exercises conducted by the State, which are relevant to a particular industrial sector, and the risk that rests with the developer to complete an EIA and apply for consent for a defined project. In situations without an automatic requirement for an SEA to be completed, industry-led initiatives that follow similar assessment criteria can be implemented to produce baseline environmental information, for example, Regional Environmental Assessments used by the marine sand and gravel dredging sector (see http://www.bmapa.org/regulation_and_management/regional_assessment.php, accessed 3 November 2018).

In support of its role, Historic England has produced or supported the production of guidance material for seabed developers on how they should include archaeology within EIAs. In most instances this guidance is thematic and tailored to the specific requirements of particular marine industries, such as marine sand and gravel (aggregate) dredging, the ports sector and offshore renewable energy infrastructure (Wessex Archaeology 2007; Oxford Archaeology 2008; Firth 2013; Cooper and Gane 2016). For example, when an EIA concludes that harmful or other 
damaging impact is possible, consent conditions can be imposed on the development to steer the delivery of mitigation work within a legal framework. Examples of such conditions are as follows:

- Archaeological interpretation of geophysical and geotechnical data acquired by developers will be subject to analysis and interpretation by professionally accredited and experienced archaeological contractors. Technical reports produced within defined time periods should be agreed and published results made publicly available through an online national archive system.

- Archaeological Exclusion Zones are to be declared by the developer (i.e. Consent Holder) so that identified seabed anomalies of known or possible archaeological interest are avoided by all project contractors conducting seabed-impacting operations.

- Reporting procedures should be adopted by all project contractors, so that if, during delivery of the project, any further materials of possible archaeological interest are encountered, appropriate action can be taken by all parties.

Historic England is also aware that seabed development projects generate a data legacy which can be used to support further archaeological research. For example, seismic data acquired by developer-led marine surveys in the North Sea between Dogger Bank and around the margins of the Outer and Inner Silver Pits was subsequently used to generate new interpretations of palaeoenvironmental landscape sequences (Gaffney et al. 2007). We therefore hope to encourage new partnerships with academic research interests that align with Historic England's published research priorities (see https://historicengland.org.uk/ images-books/publications/he-corpplan-2017-20/, accessed 3 November 2018), the maritime archaeological research agenda for England (Ransley et al. 2013), the North Sea Prehistory Research and Management Framework (Peeters et al. 2009) and the UK Marine Science Strategy (HM Government and Devolved Administrations 2010). Such collaborative action should maximise the potential of the data archives generated by developers and curated through the Marine Data Exchange (see http://www.marinedataexchange.co.uk/, accessed 3 November 2018). International partnerships are also to be promoted to examine submerged prehistoric environmental conditions and to develop effective approaches to assessment, as demonstrated to date by the results of effective collaborative exercises, for example, the former REC survey programme and development-led archaeology work programmes (Dix and Sturt 2011; Salter et al. 2014).

\subsection{Marine Development and Assessment of Underwater Cultural Heritage}

When a seabed development project requires an EIA to be completed, the assessment will examine the diverse nature of the historic environment as might be encountered using a variety of investigative techniques. The first phase of analysis, conducted by consultants appointed by the developer, is to review relevant published and unpublished documents and reports (i.e. grey literature) which may have been produced for other research purposes or as part of assessment exercises for other developments. It is also worth emphasising that for marine development projects, especially those concerned with offshore renewable energy infrastructure, considerable expenditure is invested in primary data acquisition of seabed features as a necessary part of the construction project, which will then inform mitigation programmes that may be required as a result of the EIA conclusions.

The data gathered through survey programmes should provide complete coverage of the proposed marine development area. For example, for an offshore wind farm, the area should include the turbine array and the electricity export cable route to shore. It is also important to determine how change, as brought about by the proposed development, might have an impact on the significance of any cultural heritage. In this regard, 
it is relevant to highlight that not all impacts are necessarily negative; a development project can make a positive impact through supporting the publication of professionally produced information that expands knowledge about the historic environment, and this is recognised in the published SEA Environmental Report for Offshore Energy (Department of Energy and Climate Change, 2016).

\subsubsection{The Written Scheme of Investigation}

A key part of Historic England's advice to developers during the early stages of project planning is to explain the importance of designing survey campaigns to include archaeological objectives, so that data generated are sufficient to support archaeological interpretation and analysis, for example, to reveal sub-seabed prehistoric sedimentary sequences of possible archaeological interest. During this early stage, Historic England discusses with the developer and their professional archaeological consultants the scope of a document known as an archaeological Written Scheme of Investigation (WSI). The use of WSIs is well established for terrestrial development projects and has now been adapted to serve marine development activities.

A standard aspect of EIA exercises, particularly for offshore wind farms, is to consider a wide range of engineering designs that could be used to deliver the total energy output limit for the development, should permission be obtained. For example, different electricity-generating wind turbines of different capacities could be employed using different foundation designs, each with a different impact on the cultural heritage. Consent for the development will be informed by the worst-case scenario- the design that has the greatest potential impact. It usually follows from this that the developer has to commission additional high-resolution marine survey to inform delivery of the final project design. The preparation of a draft or outline WSI as a supporting document within the application for consent is a crucial step to be taken by the developer to demonstrate how archaeological analysis and interpretation will be completed as part of the construction programme.

The draft WSI is prepared concurrently with the production of the EIA and should set out methods of archaeological analysis to be employed if the project is approved. This is a crucial condition for the granting of consent for the project. Thereafter, during the post-consent period, once the final design for the project is selected, the WSI will be used to support the archaeological interpretation of survey data commissioned at all stages of the project, including pre-construction, construction and post-construction.

The WSI should include several components. First, it will detail desk-based sources of information in local and national archives such as records of prehistoric material, as derived from the original EIA, about the character of the historic environment. Secondly, The WSI will include methodologies for the interpretation of geophysical data such as side-scan sonar, multibeam bathymetry, magnetometer and sub-bottom seismic profiling, all of which can produce different visualisations of seabed topography and subseabed sedimentary structures. These in their turn can indicate the presence of buried landscape features such as former river and terrace systems with potential to contain organic sediments of palaeoenvironmental significance and archaeological material.

Finally, it will produce survey-specific method statements on how data collected will inform archaeological interpretation, for example, the use of shallow seismic data collected along the route of electricity export cables. It is from these method statements that information is generated to produce the final technical reports.

The draft technical reports will be reviewed by local and national curators, that is, archaeologically trained personnel employed by local planning authorities and Historic England, to check that it complies with established professional archaeological practice (see https://www.archaeologists.net/, accessed 3 November 2018), and a final report will be produced by the consultant employed by the developer and formally agreed 
in accordance with a specified time frame with the regulatory authority. Failure by the Consent Holder (i.e. the company responsible for the development) to comply with the conditions of consent, such as archaeological mitigation, carries the risk of enforcement action against the developer.

A key instrument to demonstrate completion of these defined tasks is deposition of completed reports, within an agreed time frame, with a UK online archive system known as OASIS (Online AccesS to the Index of archaeological investigations (see http://oasis.ac.uk/pages/wiki/Main, accessed 3 November 2018) (for examples see Table 26.1). From here reports can be uploaded as publicly available documents to the website maintained by the Archaeological Data Service (ADS) (see archaeologydataservice.ac.uk/

Table 26.1 Examples of completed geoarchaeological reports and submission of OASIS forms to enable access through local Historic Environment Records (HERs) and their respective national Heritage Bodies within the UK

\begin{tabular}{|c|c|c|}
\hline $\begin{array}{l}\text { Offshore } \\
\text { wind farm }\end{array}$ & $\begin{array}{l}\text { Geoarchaeological } \\
\text { reports }\end{array}$ & OASIS ID \\
\hline $\begin{array}{l}\text { Gunfleet } \\
\text { Sands } \\
\text { (Thames } \\
\text { Estuary) }\end{array}$ & $\begin{array}{l}\text { Archaeological } \\
\text { recording of } \\
\text { geotechnical cores }\end{array}$ & $\begin{array}{l}\text { Englishh1-87577 } \\
\text { (2007); } \\
\text { Englishh1-87573 } \\
\text { (2008); } \\
\text { Maritime2-169743 } \\
\text { (2013) }\end{array}$ \\
\hline $\begin{array}{l}\text { Hornsea } \\
\text { ONE } \\
\text { (North Sea) }\end{array}$ & $\begin{array}{l}\text { Geoarchaeological } \\
\text { assessment report }\end{array}$ & $\begin{array}{l}\text { Maritime2-324357 } \\
\text { (2018) }\end{array}$ \\
\hline $\begin{array}{l}\text { Hornsea } \\
\text { TWO } \\
\text { (North Sea) }\end{array}$ & $\begin{array}{l}\text { Assessment of } \\
\text { borehole and } \\
\text { vibrocore logs }\end{array}$ & $\begin{array}{l}\text { Wessexar1-164773 } \\
\text { (2013) }\end{array}$ \\
\hline $\begin{array}{l}\text { Humber } \\
\text { Gateway } \\
\text { (North Sea) }\end{array}$ & $\begin{array}{l}\text { Assessment of } \\
\text { borehole and cone } \\
\text { penetrometer tests }\end{array}$ & $\begin{array}{l}\text { Wessexar1-155988 } \\
\text { (2013) }\end{array}$ \\
\hline $\begin{array}{l}\text { London } \\
\text { Array } \\
\text { (Thames } \\
\text { Estuary) }\end{array}$ & $\begin{array}{l}\text { Organic material } \\
\text { recovered during } \\
\text { benthic fish } \\
\text { surveys }\end{array}$ & $\begin{array}{l}\text { Gifford1-198856 } \\
\text { (2015); } \\
\text { gifford1-271153 } \\
(2016)\end{array}$ \\
\hline $\begin{array}{l}\text { Lynn and } \\
\text { Inner } \\
\text { Dowsing } \\
\text { (North Sea) }\end{array}$ & $\begin{array}{l}\text { Geoarchaeological } \\
\text { assessment. Final } \\
\text { report }\end{array}$ & $\begin{array}{l}\text { Wessexar1-59263 } \\
\text { (2009) }\end{array}$ \\
\hline $\begin{array}{l}\text { Westermost } \\
\text { Rough } \\
\text { (North Sea) }\end{array}$ & $\begin{array}{l}\text { Analysis of } \\
\text { borehole and } \\
\text { vibrocore material }\end{array}$ & $\begin{array}{l}\text { hampshir2-157098 } \\
\text { (2013) }\end{array}$ \\
\hline
\end{tabular}

archives/view/greylit/, accessed 3 November 2018).

Effective mitigation following the procedures outlined above can produce new knowledge and understanding and, in some cases, has resulted in publication in the specialist literature, for example, the data generated by the Dudgeon offshore wind farm (Brown et al. 2018).

\subsection{Seabed Development and Other Mitigation Measures}

The preparation of a project-specific archaeological WSI starts the process of mitigation after consent has been granted, so that identifiable seabed anomalies and sub-seabed features identified in the EIA exercise of potential archaeological or historic interest are dealt with in an agreed manner. It is a shared goal between any seabed developer and Historic England that a primary strategy to reduce risk of impact is by avoidance and in situ protection. This approach is delivered using Archaeological Exclusion Zones (AEZs), which are spatially delineated around the anomaly or other feature of interest. While this approach might be readily deliverable for a feature such as a shipwreck, the preferred approach to deliver appropriate mitigation for areas of seabed containing prehistoric landscape features is through the production of models of sedimentary sequences based on sub-bottom geophysical data and corroborated with geotechnical material (e.g. data from boreholes and vibrocores). In some instances, early involvement in survey planning, as part of WSI implementation, allows additional data to be acquired that directly support palaeoenvironmental analysis. This type of mitigation for identified elements of submerged prehistoric landscapes is appropriate given that access to such buried features could be compromised in the future if seabed infrastructure such as cables and foundations are likely to be left in situ over a wide area of seabed.

To support the production of sedimentary deposit models, Historic England commissioned guidance on offshore geotechnical investigations 
and archaeological analysis through the former Collaborative Offshore Wind Research into the Environment (COWRIE) Group. An important aspect of this guidance was to explain how the acquisition of geotechnical material should be planned to include archaeological objectives and to deliver mitigation through the geoarchaeological interpretation and modelling of palaeoenvironmental features (Gribble and Leather 2011). Established working practice for palaeoenvironmental analysis of geotechnical material frequently includes phased interpretation of materials, from visual inspection of logged sediment sequences in cores through to radiocarbon dating and identification of pollen, microcharcoal, molluscs and ostracods. For example, geotechnical vibrocore material obtained from the NEMO submarine electricity interconnector cable project at a location $12 \mathrm{~km}$ off Ramsgate (Kent) revealed the presence of successive environments including early Holocene freshwater conditions within a possible wooded river valley comprised predominantly of pine and hazel trees and considered typical of the Early Mesolithic period (Wessex Archaeology 2015).

Although a sedimentary deposit model is designed to illustrate submerged prehistoric landscape complexity, site-specific prehistoric finds do occur, such as the discovery in 2008 of 28 flint handaxes originating from in situ contexts and estimated to be around 250,000 years old; the handaxes derived from gravel dredged from a licensed marine aggregate area $13 \mathrm{~km}$ off Great Yarmouth in the southern North Sea. Following this discovery, and in partnership with the dredging operator, Historic England supported a number of studies to determine the extent of the archaeological materials within the active dredging area and also to devise appropriate monitoring procedures to determine whether handaxes in primary context existed adjacent to the dredging zone within Area 240 (Wessex Archaeology 2011; Russell \& Tizzard 2011; Salter et al. 2014; Tizzard et al. 2014, 2015; see also Bailey et al., Chap. 10, this volume). The original find location in Area 240 remains subject to a voluntary exclusion zone to avoid any further direct impact by dredging operations. This approach of working with industry is essential, as archaeological protection through area-based statutory designation is not possible within Area 240, since the finds occur in the absence of any evidence of humanbuilt structures, which is a key criterion within existing legislation for historic environment protection in England.

\subsection{Reporting of Archaeological Discoveries}

Once consent has been obtained for an offshore development project, there will be specified conditions attached to the consent, which must be delivered by the developer. To address a situation in which an archaeological site or other material of archaeological interest is unexpectedly encountered during construction works, a reporting protocol is used to ensure appropriate action, including the following:

- The site is avoided by all subsequent seabedimpacting activities associated with delivery of the consented development to reduce risk of further disturbance.

- If the particular activity resulted in the recovery, inadvertently, to the surface of material of possible historic or archaeological interest, the protocol will explain how to identify such materials and how to correctly store the items.

- Procedures for notifying the relevant parties internal and external to the development project to reduce delay in subsequent decision-making.

To assist effective implementation, guidance has been published specifically for the offshore renewable energy sector to inform the preparation of reporting procedures, so that archaeological reporting protocols can follow a standard format, which can be adapted to individual projects (The Crown Estate 2010, 2014). The reporting protocol can be used at any stage such as during preliminary offshore environmental assessment exercises. For example, the protocol was used to report archaeological interests associated with peat blocks obtained from a benthic 
trawl survey campaign for possible offshore wind farm development on the Dogger Bank (central North Sea). The subsequent programme of palaeoenvironmental assessment revealed evidence of a now drowned terrestrial environment from around 12,000-8000 years ago (Russell and Stevens 2014).

\subsection{Professional Development and Training}

To support ongoing professional development, Historic England has either delivered or commissioned training events to ensure that curators (both national and local), developers and archaeological consultants have the opportunity to maintain skills and knowledge about how the historic environment is included within development assessment exercises. Technical training is also highly relevant given the speed of technological change in survey data-gathering platforms and processing software. To support this objective, to date, the following courses have been commissioned:

- Marine renewable energy developments and the historic environment (Department for Continuing Education, University of Oxford) in March 2014.

- Marine geotechnical training course for archaeologists (National Oceanographic Centre, Southampton) in January 2015 (see https://www.southampton.ac.uk/coars/services/geoarchcpd.page, accessed 3 November 2018).

- Marine geophysical survey techniques for archaeologists (National Oceanographic Centre, Southampton) in January 2017.

- Coastal development and the historic environment (Historic Environment Local Management programme) in September 2018 (see https://historicengland.org.uk/servicesskills/training-skills/helmtraining/, accessed 3 November 2018.

Overall, the publication of thematic advice for the marine renewable power generation sector now equips developers with the information necessary to select viable strategies for data capture to deliver the necessary mitigation. It also gives curators the confidence to review and question the technical reports produced. These courses have helped to build on published guidance, such as that available for marine geophysical survey data (Plets et al. 2013). However, it is likely that HE will have to re-commission these training events since techniques both in data capture and processing are constantly changing and also to ensure that new staff members within curatorial bodies, consultancies and the developers themselves are familiar with the effective inclusion of cultural heritage as part of project planning, examination and delivery.

\subsection{Conclusions}

Historic England is the national curator for the marine environment and it provides advice to developers, their archaeological consultants and regulators for projects within the English inshore and offshore areas. It has supported the publication of guidance targeted at different marine industry sectors and will continue to commission projects to address key issues as necessary to support effective management of the historic environment. It is therefore important that such effort is described in terms of a constructive approach based on an understanding of how change, such as new seabed infrastructure projects, may affect the historic environment (see https://historicengland.org.uk/advice/constructive-conservation/conservation-principles, accessed 3 November 2018). Such an approach is based on identifying risk to known and unknown features of the historic environment within the development area. Central to this approach is to ensure that survey campaigns are effectively planned to increase our understanding about the historic environment through the analysis of developer-generated survey data. This matter is reflected in national policy used to support regulatory decision-making, so that completed assessments deliver effective description and 
analysis of environmental data including cultural heritage.

This approach is also based on the premise that the positive outcomes from offshore development in terms of new knowledge and wider understanding are dependent on completion of defined programmes of work to professional archaeological standards. Such an approach not only has scientific value but should also encourage greater public understanding and appreciation of the underwater cultural heritage and the ways in which its study contributes to a better understanding of environmental change. A good example is the recent British media interest in the evidence of a prehistoric landscape found during survey work for a proposed offshore wind farm in the southern North Sea (BBC Online at https://group.vattenfall.com/uk/newsroom/news-press-releases/pressreleases/stories/ will-the-secrets-of-doggerland-be-revealed-byunique-find-at-north-sea-site).

Much of the work described above is coming about as the result of a huge investment in renewable sources of energy, particularly offshore wind farms, in response to climate change. It is therefore highly appropriate that examination of the cultural heritage associated with these developments fully embraces analysis of prehistoric environments and contributes to the modelling of past climates, conditions as experienced by past peoples and a better appreciation of how the environment changes over time. In Historic England, we see this as an important exercise that can be used to support public communication and explanation about how environments change and why action is necessary to address climate change as it affects the world we live in today.

Acknowledgements Thanks are due to Edward Salter (formerly of English Heritage and now of The Crown Estate, London) for help in preparing the presentation given at the SPLASHCOS Conference 'Offshore Industry and Archaeology: a creative relationship' in Esbjerg, Denmark, on 14 March 2013, to Thijs Maarleveld for his original invitation to the conference and to Geoff Bailey, Hans Peeters and an anonymous reviewer for helpful comments that have improved the text.

\section{References}

Brown A, Russell J, Scaife R, Tizzard L, Whittaker J, Wyles SF (2018) Lateglacial/early Holocene palaeoenvironments in the southern North Sea Basin: new data from the Dudgeon offshore wind farm. J Quat Sci 33(6):597-610

Cooper V, Gane T (2016) The assessment and Management of Marine Archaeology in port and harbour development. Wessex Archaeology, Salisbury

Department of Energy and Climate Change (2016) UK offshore energy strategic environmental assessment (UK OESEA3) environmental report. The Stationary Office, London. https://www.gov.uk/government/collections/ offshore-energy-strategic-environmental-assessments

Dix JK, Sturt F (2011) The relic Palaeo-landscapes of the Thames estuary. MALSF, London

Firth A (2013) Historic environment guidance for wave and tidal energy. Fjordr, Wiltshire

Gaffney V, Thomson K, Fitch S (eds) (2007) Mapping Doggerland: The mesolithic landscapes of the Southern North Sea. Archaeopress, Oxford

Gribble J, Leather S (2011) Offshore geotechnical investigations and historic environment analysis: guidance for the renewable energy sector. COWRIE, London

HM Government and Devolved Administrations (2009) Our seas: a shared resource, high-level marine objectives. Department for Environment, Food and Rural Affairs, London. https://www.gov.uk/government/ publications/our-seas-a-shared-resource-high-levelmarine-objectives

HM Government and Devolved Administrations (2010) UK marine science strategy. Department for Environment, Food and Rural Affairs, London. https://www.gov.uk/government/publications/ uk-marine-science-strategy-2010-to-2025

HM Government and Devolved Administrations (2011) UK marine policy statement. The Stationary Office, London. https:/www.gov.uk/government/ publications/uk-marine-policy-statement

Oxford Archaeology (2008) Cumulative impact assessment and the marine historic environment. Oxford Archaeology/George Lambrick Archaeology and Heritage, Oxford

Pater C, Oxley I (2014) Developing marine historic environment management policy: the English Heritage experience. Mar Policy 45:342-348

Peeters H, Murphy P, Flemming N (2009) North Sea prehistory research and management framework. Rijksdienst voor het Cultureel Erfgoed, Amersfoort

Plets R, Dix J, Bates R (2013) Marine geophysics data acquisition, processing and interpretation guidance notes. English Heritage, London

Ransley J, Sturt F, Dix J, Adams J, Blue L (eds) (2013) A maritime archaeological research agenda for England, CBA Research Report, vol 171. Council for British Archaeology, York 
Russell JW, Stevens CJ (2014) Palaeoenvironmental assessment of peat samples. The Crown Estate, London

Russell JW, Tizzard L (2011) Seabed prehistory: site evaluation techniques (area 240) synthesis. Wessex Archaeology, Salisbury

Salter E, Murphy P, Peeters H (2014) Researching, conserving and managing submerged prehistory: national approaches and international collaboration. In: Evans AM, Flatman JC, Flemming NC (eds) Prehistoric archaeology on the continental shelf: a global review. Springer, New York, pp 151-172

The Crown Estate (2010) Model clauses for archaeological written schemes of investigation. The Crown Estate, London. https://www.wessexarch.co.uk/sites/ default/files/field_file/4_WSI\%20Renewables.pdf

The Crown Estate (2014) Protocol for archaeological discoveries: offshore renewables projects. Wessex Archaeology, Salisbury. https://www.thecrownestate. co.uk/media/1782/ei-protocol-for-archaeological-discoveries-offshore-renewables-projects.pdf

Tizzard L, Bicket AR, Benjamin J, De Loecker D (2014) A middle Palaeolithic site in the southern North Sea: investigating the archaeology and palaeogeography of area 240. J Quat Sci 29(7):698-710

Tizzard L, Bicket AR, de Loecker D (2015) Seabed prehistory: investigating the palaeogeography and early middle Palaeolithic archaeology in the southern North Sea, Wessex archaeology report 35. Wessex Archaeology, Salisbury

Wessex Archaeology (2007) Historical environment guidance for the offshore renewables energy sector. COWRIE, London

Wessex Archaeology (2011) Licence area 240: archaeological monitoring of dredging activity. Wessex Archaeology, Salisbury

Wessex Archaeology (2015) Nemo link: archaeological stage 4 analysis. Wessex Archaeology, Salisbury

Open Access This chapter is licensed under the terms of the Creative Commons Attribution 4.0 International License (http://creativecommons.org/licenses/by/4.0/), which permits use, sharing, adaptation, distribution and reproduction in any medium or format, as long as you give appropriate credit to the original author(s) and the source, provide a link to the Creative Commons licence and indicate if changes were made.

The images or other third party material in this chapter are included in the chapter's Creative Commons licence, unless indicated otherwise in a credit line to the material. If material is not included in the chapter's Creative Commons licence and your intended use is not permitted by statutory regulation or exceeds the permitted use, you will need to obtain permission directly from the copyright holder. 